\title{
FINITE ELEMENT ANALYSIS OF R.C. INTERIOR SLAB-COLUMN JOINTS WITH RIGID REINFORCEMENT
}

\author{
Eid I.Al-Sahawneh \\ Civil Engineering Department, Faculty of Engineering Technology, \\ Al-Balqa' Applied University, Amman, Jordan
}

\begin{abstract}
Finite element modeling of reinforced concrete interior column-slab joints with and without shear reinforcement, as well as analysis of shear stress fields in the middle layer of the concrete plate were performed using STAAD.ProV8i. For proper calibration between the models, a definite finite solid model without shear reinforcement is analyzed and considered a reference sample. This study examines a new form of rigid shear reinforcement that eliminates steel congestion at joints and provides a simple approach to determining the rigid shear reinforcement arm.
\end{abstract}

Keywords: Punching shear, slab-column joint, rigid shear reinforcement, finite element modeling, staad pro

Cite this Article: Eid I.Al-Sahawneh, Finite Element Analysis of R.C. Interior SlabColumn Joints with Rigid Reinforcement, International Journal of Civil Engineering and Technology, 11(8), 2020, pp. 14-23.

https://iaeme.com/Home/issue/IJCIET?Volume $=11 \&$ Issue $=8$

\section{INTRODUCTION}

The first attempt to incorporate various types of transverse reinforcement into flat plates was performed by Graf and Wheeler by using bent-up bars. It was observed that bent-up bars increased the punching shear resistance. Islam and the Park [1], Hannah et al. [2], Pillai et al. [3] and Robertson et al. [4] used vertical stirrups with additional horizontal bars extending outward from the support in two perpendicular directions as another type of punch shear increase as in Figure 1. The ACI 318-19M section 22.6.7.1 [5] requires, when using vertical stirrups for increasing punching shear, that the slab effective depth $d$ to be at least $15 \mathrm{~cm}$, but not less than 16 times the diameter of the shear reinforcement. Regan and Samadian [6], Oliveira et al. [7] noted that only inclined stirrups, with a $60^{\circ}$ inclination, have shown to be efficient in increasing the punching resistance. 


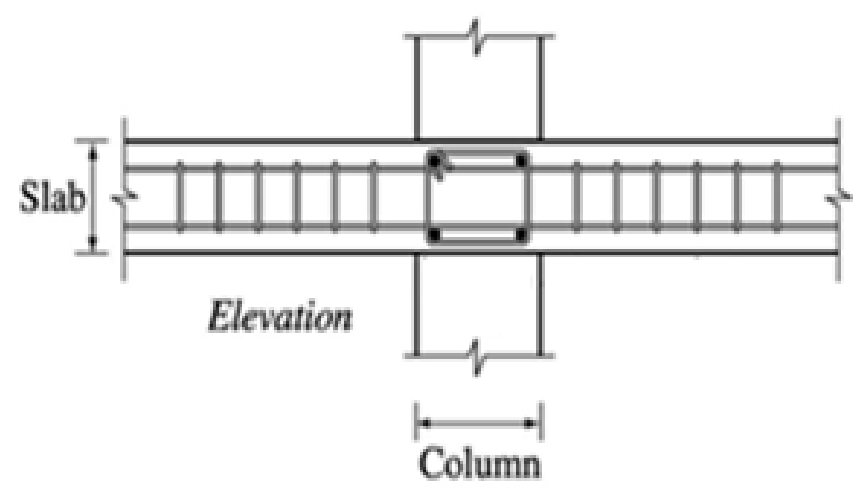

Figure 1 Flat Closed stirrups shear reinforcement for slabs at slab-column connections.

The most popular punching shear reinforcement in the civil construction industry today, is headed shear studs welded to a steel plate as in Figure 2. Shear studs and stud rails were used in slabs and tested by Dilger and Ghali [8], Elgabry and Ghali [9], Megally and Ghali [10].

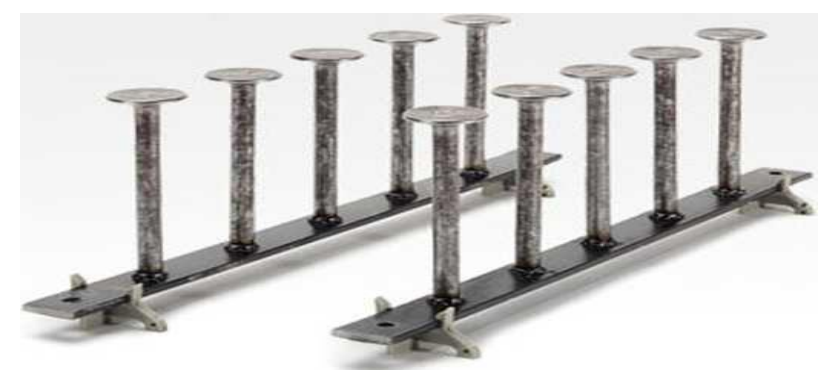

Figure 2 Shear studs (taken from Polak et al., [11]).

El-Salakawy et al. [12] presented a new type of shear reinforcement installed later in flat plates, called shear bolts as in Figure 3. Adetifa and Polak [13] observed that shear bolts prevent the propagation of the shear cracks in strengthened slabs and improve the performance of the slabs with openings.

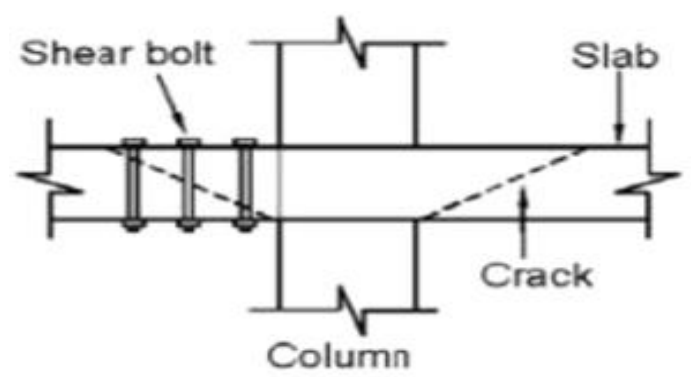

Figure 3 Shear bolt and its installation (Polak and Adetifa, [13]).

Corley and Hawkins [14] and Dilger and Gali [15] tested a new type of shear reinforcement called shearheads, shown in Figure 4. Shearheads are cross-shaped elements constructed by welding structural-steel members, such as channels, or I-beam, into a rigid unit. Shearheads are usually used to increase the effective perimeter $b_{0}$ of the critical section through which shear can be transferred into an interior column from the surrounding slab. 


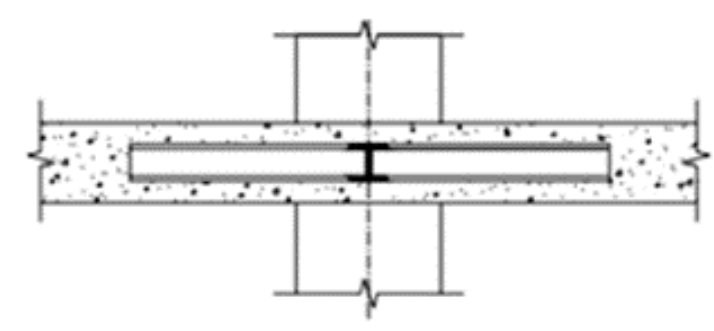

Figure 4 Shearheads shear reinforcement

\section{REVIEW OF ACI318-19M DESIGN PROVISIONS FOR PUNCHING SHEAR}

The research done by Moe in 1961 led to the ACI design provisions for punching shear. The ACI Committee 326 adopted a pseudo-critical section located at a distance $d / 2$ from the face of the column (or the perimeter of the loaded area), as in Figure 5. In this critical region, for slabs of uniform thickness, the shear strength is checked on one section. For slabs with variable thickness, it is required to check the shear at many sections.
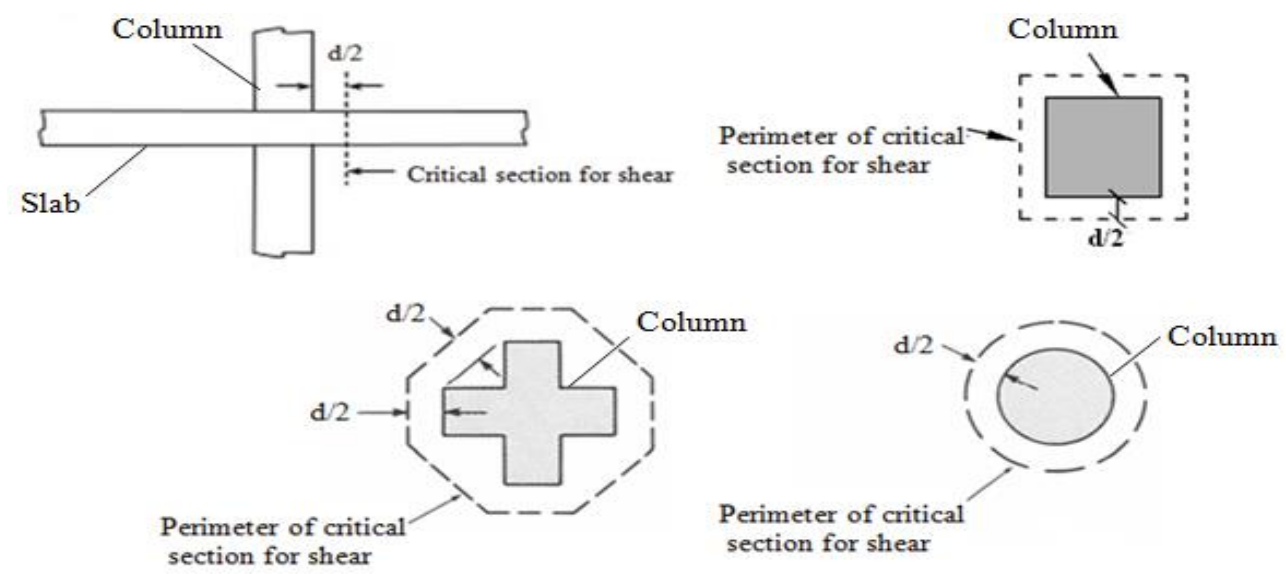

Figure 5 Perimeter Critical section according to ACI for typical flat plate (without capitals or drop panels)

The ACI Code, Section 22.6.1.3, requires that the factored shear force $V_{f}$ on the critical section should be less than $\varphi\left(V_{c}+V_{s}\right)$ where $V_{c}$ is the shear resistance provided by concrete, $V_{s}$ is the shear resistance provided by shear reinforcement, and $\varphi$ is a reduction factor. The nominal punching shear resistance of concrete for slabs without shear reinforcement according to ACI Code, Section 22.6.5.2, is:

$$
V_{c}=\min \left\{\begin{array}{c}
0.33 \lambda \lambda_{s} b_{o} d \sqrt{f_{c}^{\prime}} \\
0.17 \lambda \lambda_{s} b_{o} d \sqrt{f_{c}^{\prime}}\left(1+\frac{2}{\beta}\right) \\
0.083 \lambda \lambda_{s} b_{o} d \sqrt{f_{c}^{\prime}}\left(2+\frac{\alpha_{s} d}{b_{o}}\right)
\end{array}\right.
$$

Where, $\lambda$ is the concrete density factor equal to 1 for a normal-weight concrete, $\lambda_{s}$ is the size effect factor given in 22.5.5.1.3, $b_{o}$ is the perimeter along the critical section located $\mathrm{d} / 2$ from the face of the column, and, $d$ is the effective depth of the slab, $f_{c}^{\prime}$ is the specified compressive strength of concrete $\left(f_{c}^{\prime}\right.$ is limited to $68 \mathrm{MPa}$, and no effect of flexural 
reinforcement is considered according to ACI code, section 22.6.3.1), $\beta$ is ratio of long side of column or loaded area to short side $\alpha_{s}=40$ for an interior column, 30 for edge columns, and 20 for corner columns, where the words interior, edge, and corner refer to critical sections with 4,3, or 2 sides, respectively. The nominal punching shear resistance of slabs with shear reinforcement (stirrups) is calculated according to ACI code, section 22.6.6.1

\section{RESEARCH SIGNIFICANCE}

The study examines the distribution of shear stresses around the interior slab-column connection without rigid reinforcement using (STAAD.ProV8i) relying solely on ACI318 recommendations. The Flat plate is modeled by a 3D solid element; flexural reinforcements are modeled with a one-dimensional element, and rigid shear reinforcements are modeled with a two-dimensional element or a plate element. STAAD.ProV8i software helps to model any shape of rigid shear reinforcement and the embedment condition of rigid reinforcement into concrete is done using the interaction module of meshing, which provides bonding between steel and concrete.

\section{STRUCTURAL FINITE ELEMENT MODEL}

The interior column and the flat plate are replaced with three-dimensional solid elements. Flexural reinforcement bars have a line shape that represents the actual size and location and is embedded in the solid finite element by meshing. The refined fragment model is shown in Figure 6. The geometric characteristics of the refined fragment model were as follows: the length of the column was taken equal to $1 \mathrm{~m}$ below the concrete plate and $1 \mathrm{~m}$ above the plate; it is assumed that the area of the concrete plate is $5 \mathrm{~m} \mathrm{x} 6 \mathrm{~m}$; the thickness of the concrete plate is $20 \mathrm{~cm}$; the concrete column section is $40 \mathrm{~cm} \times 40 \mathrm{~cm}$; flexural reinforcement bars have a diameter of $16 \mathrm{~mm}$ and are spaced $15 \mathrm{~cm}$ center to center in two perpendicular directions.Types of finite elements of the refined fragment model were: concrete column and concrete flat plate - eight-node isoparametric solid element; reinforcement bar - spatial bar; steel plate is a meshed plate element. The partitioning step of the solid elements is $0.05 \mathrm{~m}$. The characteristic compressive strength $f_{c}^{\prime}$ of concrete, given in the model, is $28 \mathrm{MPa}$ with Young's modulus value of $24.87 \mathrm{GPa}$ and Poisson's ratio value of 0.17 . Similarly, Young's modulus value of steel is given as $200 \mathrm{GPa}$ with Poisson's ratio of 0.3 . Steel reinforcement behaves elastically up to the Von Mises yield stress of $420 \mathrm{MPa}$ for round deformed bars and $248 \mathrm{MPa}$ for steel plates.

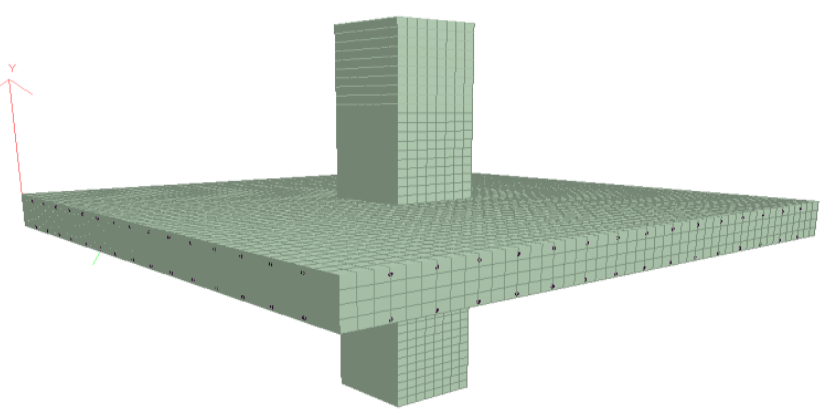

Figure 6 .The refined fragment model of the interior column-plate connection with embedded flexural reinforcement 


\section{SHEAR STRESS FIELDS}

\subsection{Reference Shear Stress Diagram, Model №1}

The first case, model №.1 includes the computation of the axial compressive force $P_{u}$ generated in the interior column due to the shear stress initiated in the critical section at distance $\mathrm{d} / 2$ from the column faces, which have a value computed according to ACI 318 19M.Table 22.6.5.2. Model №.1 has flexural reinforcement, but does not have rigid shear reinforcement and is considered a calibrated model. The design maximum load $P_{u}$, that can be applied to the interior column and does not lead to punching failure of the concrete plate, is computed by ACI 318-19M. Table 22.6.5.2, formulae and the values of the generated shear stress' fields in the plate are considered as the maximum allowable shear stress that can be resisted by concrete.

$$
\begin{gathered}
P_{u}=V_{u}=\min \text { of } \\
\left\{\begin{array}{c}
0.75 \cdot 0 \cdot 33 \cdot 1 \cdot \sqrt{28} \cdot 174 \cdot 4 \cdot 574 \cdot 10^{-3}=523.21 \mathrm{kN} \\
0.75 \cdot 0 \cdot 17 \cdot\left(1+\frac{2}{1}\right) 1 \cdot \sqrt{28} \cdot 174 \cdot 4.574 \cdot 10^{-3}=808.59 \mathrm{kN} \\
0.75 .0 .083 \cdot\left(2+\frac{40.174}{574}\right) 1 \cdot \sqrt{28} \cdot 174.4 .574 \cdot 10^{-3}=1858.84 \mathrm{kN}
\end{array}\right.
\end{gathered}
$$

The shear stress fields in the column-plate joint region due to the applied axial force $P_{u}=523.21 \mathrm{kN}$ in the interior column, as shown in the Figure7 and Figure 8.

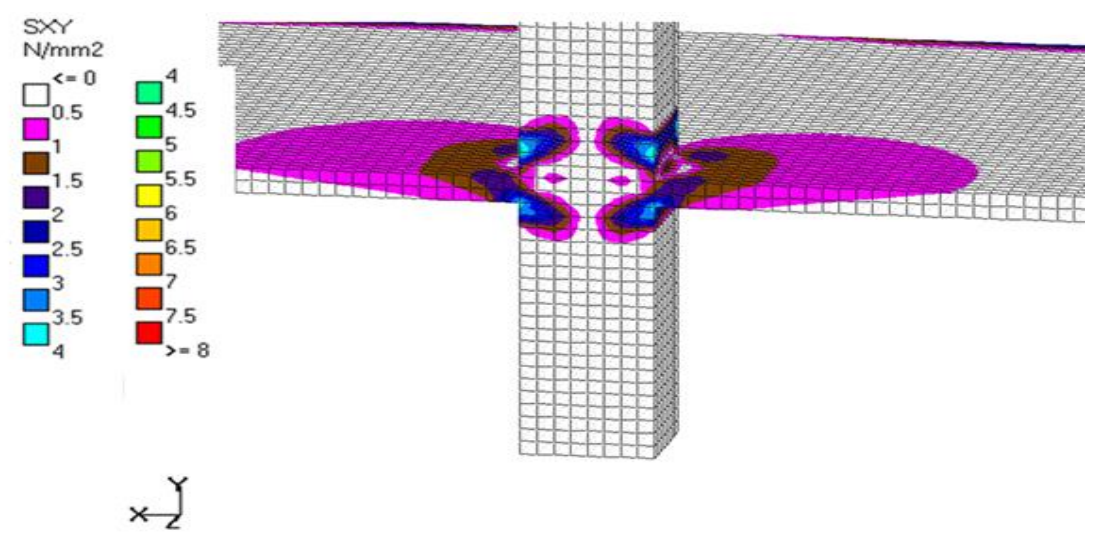

Figure 7 Distribution of absolute values of shear stress fields $\tau_{x y}$ in the middle layer of plate thickness, which can be resisted individually by concrete plate

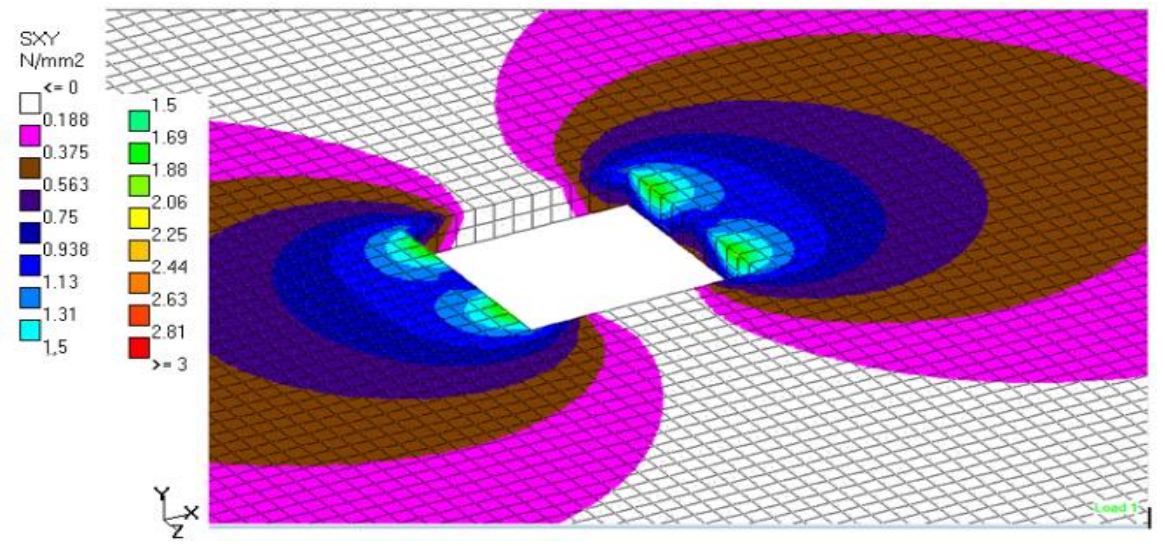

Figure 8 Absolute values of shear stress fields' $\tau_{\mathrm{xy}}$ in the middle layer of plate thickness at different distances from critical section perimeter. 
Shear stress values, as a rule, should not exceed 1.3 MPa over the area of the critical section for model №.1, but locally; narrowly limited zones are observed in the middle layer of plate thickness where the shear stress values exceed 30-45\%, as shown in Figure 8.The maximum shear stress values obtained are assumed to be permissible, and when they occur in the concrete, the joint should not fail by punching. The reference diagram of shear stress in the control model №.1, as shown in Figure 9, is constructed for the most stressed section based on STAAD.ProV8i results

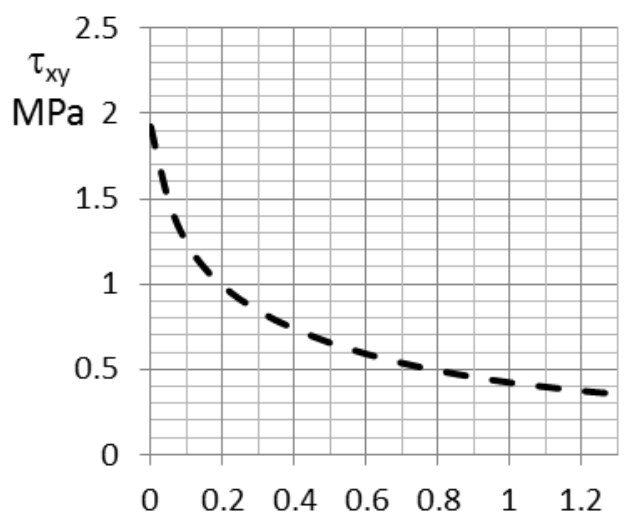

Distance measured from the critical section, $m$

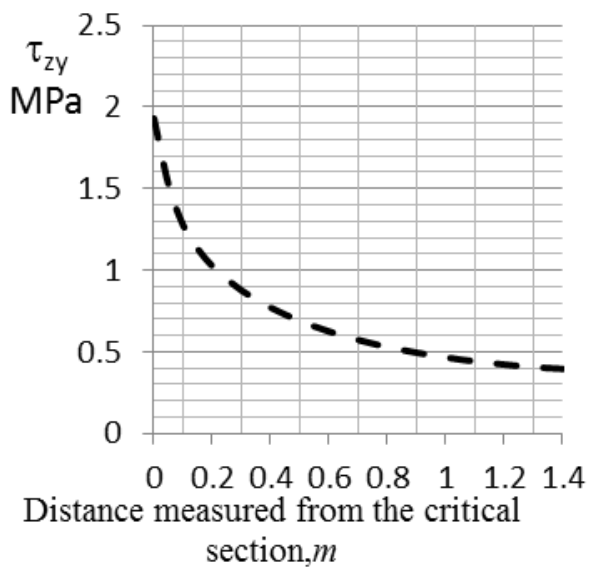

in the control model

Figure 9 Reference diagrams of shear stresses $\tau_{\mathrm{xy}}$ and $\tau_{\mathrm{zy}}$ in the middle layer No.1.

\subsection{Shear Stress Diagram with Rigid Reinforcement, Model № 2.}

By increasing the applied axial load up to $P_{u}=796 \mathrm{kN}$, the shear stresses values here, in the model No.2, are increased by $37-40 \%$. This means that the concrete in the design critical section cannot resist alone the new $P_{u}$; therefore, additional shear reinforcement is required for punching shear resistance. Additional reinforcement, consisting of separated four plates bent at $90^{\circ}$, is located at the corners of the interior column, starting with an initial thickness of $5 \mathrm{~mm}$ and a constant height of $160 \mathrm{~mm}$, and arranged in pairs in two mutually perpendicular directions, as illustrated in Figure 10. The axes of the plates are displaced symmetrically from the axes of the column at a distance of $150 \mathrm{~mm}$, noting that stresses in the model № 2 concrete with the introduction of rigid reinforcement should not exceed the maximum values of the reference diagram and the shear stress fields to ensure that the punching failure does not occur.

The effective perimeter for shear of the critical section $b_{0}$ shown in Figure 10 is determined from geometry, with $b_{0}$ expressed in terms of $l_{\mathrm{v}}$ as in equation 2 .

$$
b_{0}=4 \cdot \sqrt{2\left(\frac{l_{v}-c}{2}\right)^{2}}+4 c
$$

Where:

$l_{v}=$ the overall distance between the outermost edges of shearheads arms in one direction; $\mathrm{c}=$ side size of the square column. The ultimate allowable load at new section as per ACI318-19M section 22.6.9.8 recommendations

$$
P_{u}=V_{u}=\emptyset \cdot 0 \cdot 33 \cdot \lambda \cdot \lambda_{s} \cdot \sqrt{f_{c}^{\prime}} \cdot b_{0} \cdot d
$$




$$
P_{u}=0.75 .0 .33 .1 .1 \cdot \sqrt{f_{c}^{\prime}} \cdot\left(4 \cdot \sqrt{2\left(\frac{l_{v}-c}{2}\right)^{2}}+4 c\right) \cdot d
$$

Then, the required length $l_{v}$ is found by transposing the preceding equation 3 ; we get the dependence of $l_{v}$ on $P_{u}$ :

$$
l_{v}=\frac{P_{u}}{\text { 0.7.d. } \sqrt{f_{c}^{\prime}}}-0.4 c
$$

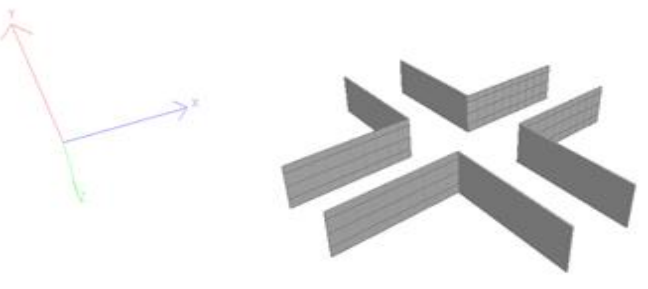

(a)

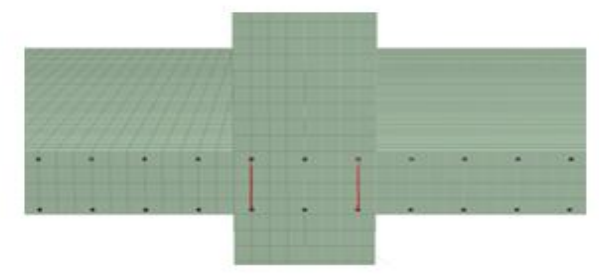

(b)

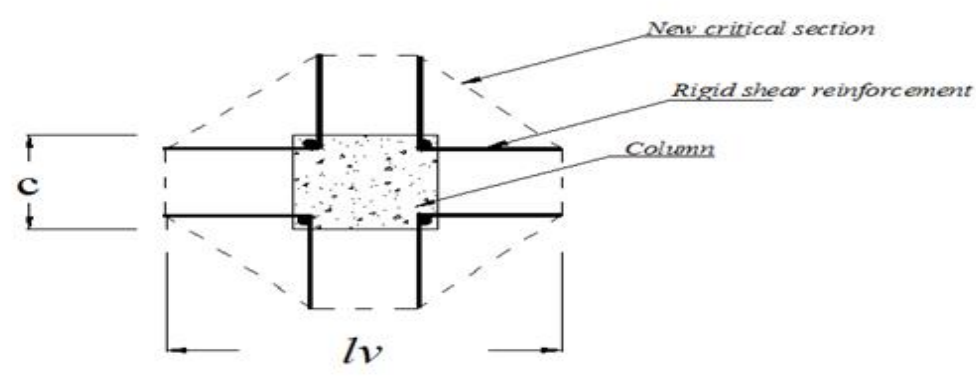

(c)

Figure 10 (a) The proposed four steel plates A36 (b) Steel plates embedded into the joint, model No.2 (c) Plan of plate-column concrete joint reinforced with rigid shear reinforcement.

This theoretical minimum extension length of shearheads arms $l_{v}$ in one direction ensures the exclusion of punching. However, in fact, this value should be increased by the anchorage length. Since the introduction of steel plates of obviously longer length is not rational from an economic point of view, it is necessary to check the minimum length of the plates, which eliminates the punching failure of the joint. For this, several calculations with different lengths of elements of rigid reinforcement are carried out using STAAD.ProV8i program. Substituting the value of $P_{u}=796 \mathrm{kN}$ into the formula (3), we obtain $l_{v}=756.7 \mathrm{~mm}$, say $l_{v}=$ $80 \mathrm{~cm}$. The first model considered to have a length element of rigid reinforcement equal to the theoretical minimum value $l_{v}=80 \mathrm{~cm}$. In all models, the length of the elements in both directions was the same. After that, this length is increased by an amount equal to the plate thickness $h=20 \mathrm{~cm}$. The stress fields arising in the region of the plate-column connection are obtained and in accordance with these stress fields, the stress diagrams $\tau_{x y}$ and $\tau_{z y}$ were constructed in sections in which plates extend along the larger and smaller spans. Plots are presented in Figure 11. 
Finite Element Analysis of R.C. Interior Slab-Column Joints with Rigid Reinforcement

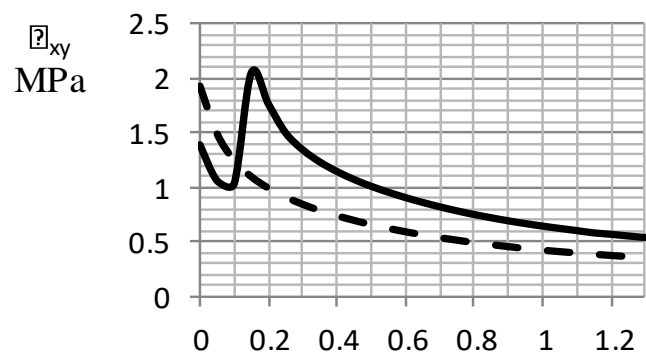

Distance measured from the critical section perimeter, $m$

- Reference stress diagram

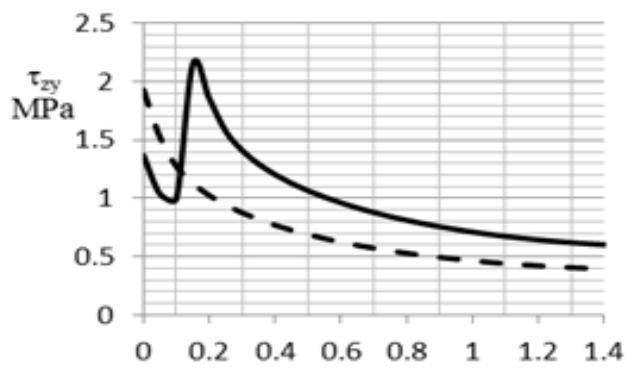

Distance measured from critical section perimeter, $m$

- - Reference stress diagram

Stress diagram in the model with $\mathrm{Iv}=80 \mathrm{~cm}$

Figure 11 Plot of stresses $\tau_{\mathrm{xy}}$ and $\tau_{\mathrm{zy}}$ in the most stressed section with $l_{v}=80 \mathrm{~cm}$

Concentrations of shear stresses, as in Fig. 9.2 and Fig.9.3, appear in places where the plate breaks. The shear stress values $\tau_{\mathrm{xy}}$ and $\tau_{\mathrm{zy}}$ are $6 \%$ and $11 \%$ higher than the allowable values, respectively. With an increase in length $l_{v}$ by $2 h$, that is, with a length $l_{v}=1.2 \mathrm{~m}$, the shear stresses do not exceed the permissible values. This is illustrated in Fig.9.8 and Fig.9.9, as well as on the graphs (Figure 12 and Figure 13).

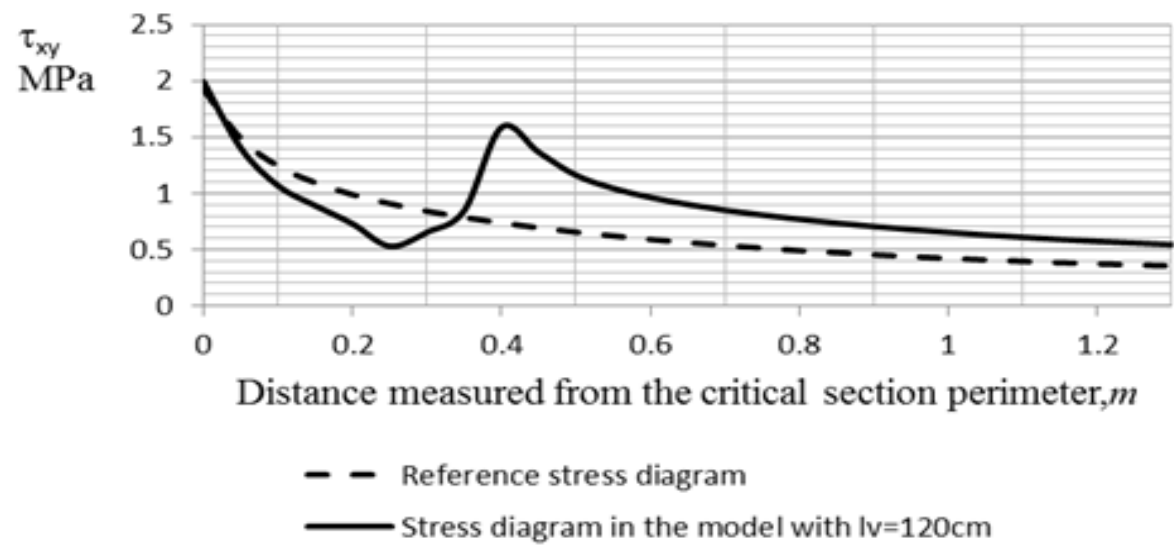

Figure 12 Plot of stress $\tau_{\text {xy }}$ in the most loaded section with $l_{v}=120 \mathrm{~cm}$

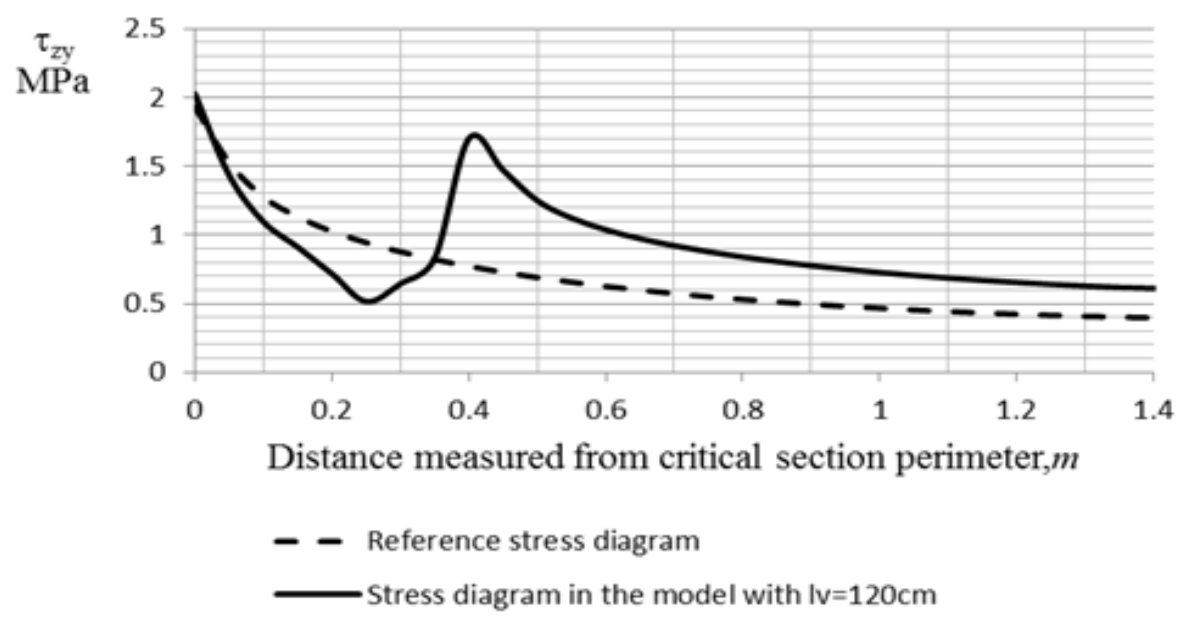

Figure 13 Plot of stresses $\tau_{\mathrm{xy}}$ and $\tau_{\mathrm{zy}}$ in the most stressed section with $l_{v}=120 \mathrm{~cm}$ 
A brief summary of the main provisions of the state of stresses arising in the steel plate with $l v=120 \mathrm{~cm}$ can be summarized as shown in Table 1 .

Table 1 Magnitude of stresses acting on the steel plate

\begin{tabular}{|c|c|c|c|c|c|c|c|}
\hline \multirow{2}{*}{ Type of stress } & \multicolumn{2}{|c|}{ Shear } & \multicolumn{3}{|c|}{ Membrane } & \multirow{2}{*}{ 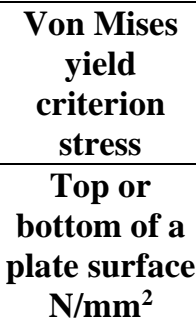 } & \multirow{2}{*}{ 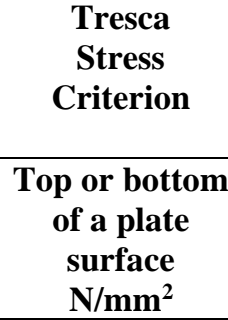 } \\
\hline & $\begin{array}{c}\tau_{\mathrm{xz}} \\
(\text { local) } \\
\mathbf{N} / \mathbf{m m}^{2}\end{array}$ & $\begin{array}{c}\tau_{\mathrm{yz}}(\text { local }) \\
\mathbf{N} / \mathbf{m m}^{2}\end{array}$ & $\begin{array}{c}\sigma_{\mathrm{x}}(\text { local }) \\
\mathbf{N} / \mathbf{m m}^{2}\end{array}$ & $\begin{array}{c}\sigma_{\mathrm{y}}(\text { local }) \\
\mathrm{N} / \mathbf{m m}^{2}\end{array}$ & $\begin{array}{c}\tau_{\mathrm{xy}} \\
(\text { local) } \\
\mathbf{N} / \mathbf{m m}^{2}\end{array}$ & & \\
\hline $\operatorname{Max} \tau_{\mathrm{xz}}$ & 5.153 & & & & & & \\
\hline $\operatorname{Min} \tau_{\mathrm{xz}}$ & -5.119 & & & & & & \\
\hline $\operatorname{Max} \tau_{\mathrm{zy}}$ & & 3.907 & & & & & \\
\hline $\operatorname{Min} \tau_{z y}$ & & -3.907 & & & & & \\
\hline $\operatorname{Max} \sigma_{\mathrm{x}}$ & & & 75.271 & & & & \\
\hline $\operatorname{Min} \sigma_{\mathrm{x}}$ & & & -78.602 & & & & \\
\hline $\operatorname{Max} \sigma_{\mathrm{y}}$ & & & & 4.963 & & & \\
\hline $\operatorname{Min} \sigma_{\mathrm{y}}$ & & & & -10.172 & & & \\
\hline Min center $\tau_{\mathrm{xy}}$ & & & & & -13.020 & & \\
\hline Max Von Mises & & & & & & 85.040 & \\
\hline Min Von Mises & & & & & & 9.876 & \\
\hline Max Tresca & & & & & & & 90.550 \\
\hline Min Tresca & & & & & & & 10.173 \\
\hline
\end{tabular}

The stresses, as illustrated in Table 1 above, do not exceed $38 \%$ of the design resistance of the metal $\mathrm{F}_{\mathrm{y}}=248 \mathrm{MPa}$. However, as the thickness of the plate decreases, the rigidity of the structure decreases, which leads to a significant increase in stresses in the concrete. Consequently, such an option of installing rigid reinforcement at the column slab connection ensures the elimination of punching.

\section{CONCLUSIONS}

According to the data presented in the research, the following conclusions can be drawn due to the Introduction of rigid reinforcement in the form of four plates arranged in pairs in two perpendicular directions.

- The shear stresses decrease significantly with increasing plate thickness, maintaining a constant plate height.

- A simple formula has been defined for calculating the minimum length of rigid reinforcement elements to withstand the punching stress at plate column connection in the form of:

$$
l_{v}=\frac{P_{u}}{0.7 \cdot d \cdot \sqrt{f_{c}^{\prime}}}-0.4 c+2 h
$$

- A new formula for the effective perimeter of the critical section for shear is determined in the form of:

$$
b_{0}=4 \cdot \sqrt{2\left(\frac{l_{v}-c}{2}\right)^{2}}+4 c
$$




\section{ACKNOWLEDGEMENT}

This work has been performed during sabbatical leave granted to the author from Al-Balqa' Applied University (BAU) during the academic year 2017/2018. The author would like to express gratitude for the support provided by the University at all stages of this work.

\section{REFERENCES}

[1] S. Islam and R. Park. "Tests on Slab-Column Connections with Shear and Unbalanced Flexure." Journal of the Structural Division, ASCE, Vol. 102, No. ST3, March 1976, pp. 544568.

[2] Hanna, S. N.; D. Mitchell and N. M. Hawkins, "Slab-Column Connections Containing Shear Reinforcement and Transferring High-Intensity Reversed Moments.", SM 75-1, Division of Structures and Mechanics, Department of Civil Engineering, University of Washington, Seattle, Washington., Aug., 1975.

[3] Pillai, S. U.; Kirk, W. and Scavuzzo, L., "Shear Reinforcement at Slab-Column Connections in a Reinforced Concrete Flat Plate Structure." Proceedings of ACT Journal, Vol. 79, No.1, Jan., 1982, pp. 36-42.

[4] Robertson, I. N., Kawai, T., Lee, J., and Enomoto, B., "Cyclic Testing of Slab-Column Connections with Shear Reinforcement," ACI Structural Journal, Vol. 99, No.5, 2002, pp.605-613.

[5] ACI (American Concrete Institute) (2019) ACI 318-19M: Building code requirements for structural concrete and commentary. ACI, Farmington Hills, MI, USA.

[6] Regan PE. Samadian F. Shear reinforcement against punching in reinforced concrete flat slabs. London. England: The Structural Engineer: 2001. pp. 24-31.

[7] Oliveira DR. Mclo OS. Regan PE. Punching strengths of flat plates with vertical or inclined stirrups. AC1 Struct J .USA 2000; 97:pp.485-91.

[8] A. Ghali, and W. Dilger, "Stud Shear Reinforcement for Flat Concrete Plates," J. ACI, vol. 82, no. 5, 1985, pp. 676-683.

[9] A. A. Elgabry and A. Ghali, 'Tests on Concrete Slab-Column Connections with Stud Shear Reinforcement Subjected to Shear-Moment Transfer," ACl Struct. J, vol. 84. no. 5,1987, pp. 433-42.

[10] S. Megally, A. Ghali Punching shear design of earthquake-resistant slab-column connections. ACI Struct. J., 97 (5) (2000)

[11] Polak, M.A., El-Salakawy, E. and Hammill, N.L. (2005). "Shear reinforcement for concrete flat slabs." ACI Special Publ .,SP-232-05:pp.75-96.

[12] El-Salakawy, E. F., Polak, M. A., Soudki, K.A., 2003, New shear strengthening technique for concrete slab-column connections, ACI Structural Journal, 100(3): pp.297-304.

[13] Adetifa, B.: Polak, M. A. 2005, Retrofit of interior slab column connections for punching using shear bolts, ACI Structural Journal 102(2):pp. 268-274.

[14] Corley. W. G., and N.M. Hawkins, "Shearhead Reinforcement for Slobs", Proceedings, ACI Journal, Vol. 65. No. 10, Oct. 1968, pp. 811-824.

[15] Dilger, W. H, and A. Ghali, 'Shear Reinforcement for Concrete Slabs', Journal of the Structural Div., ASCE, Vol. 107, ST 12, Dec. 1981, pp. 2403-2420.

[16] STAAD.ProV8i (SELECT series 6), "Technical Reference Manual", Bentley Sustaining Infrastructure. Last updated: 19 November 2016 